\title{
The Nature of Learning and Work Transitioning in Boundaryless Work: The Case of the Environmental Engineer
}

\author{
Presha Ramsarup and Heila Lotz-Sisitka, Rhodes University, South Africa
}

\begin{abstract}
Transition is a common characteristic of our lives, particularly in a rapidly changing world. In this context, how careers are enacted has become increasingly varied, requiring new conceptual tools to study the transitions of learners and workers. This paper uses theoretical constructs from the literature on boundaryless career discourse as well as learning and on work transitioning in order to explore the learning pathways of environmental engineers. It thus contributes to empirical work that articulates ongoing transitions (beyond the first job) within 'occupational and organisational life', as well as to the understanding of learning pathways as educational and occupational progression. The career stories help us to understand how non-linear transitions emerge, the complexity of these transitions, and the need to attend to broader institutional arrangements within and across education and training, the labour market and the workplace. Through its focus on the environmental engineer, it helps us to understand the processes and outcomes of transitions in an important occupation in contemporary professional work in South Africa. Finally, in a field dominated by research on entry into a first job, the paper also provides much-needed insights into occupational transitions into specialised work.
\end{abstract}

\section{Introduction}

As societies grapple with the effects of environmental degradation, occupational and educational systems have had to find the means to comprehend the implications. Several recent studies (DEA, 2010; HSRC, 2009) have highlighted many skills and competence issues related to green careers. Provisioning for workplace learning and sustainability practices is poorly constituted and unresponsive to the dynamic nature of environmental work. The environmental 'sector' has relatively new occupations that often lack clear-cut pathways into jobs. At the same time, the occupational contexts surrounding these occupations are rapidly changing with evolving skill needs. The post-school sector thus needs to support pathways into specialist jobs that do not (yet) have clear-cut routes to follow. This complexity raises several challenges. To enable more seamless and responsive transitions into environmental careers, it is critical that we broaden insights into the learning and the work transitioning that underpin environmental-learning pathways. 


\section{Theoretical Perspective}

This paper analyses the transitioning processes of environmental engineers in South Africa, and the outcomes of these processes. The analysis suggests that environmental engineers are working in what can be characterised as 'boundaryless careers' (Arthur \& Rousseau, 1996). Characteristically, boundaryless careers depict discontinuous career paths that typically go beyond the boundary of a single organisation with a defined career path.

Various authors have recognised a heightened occurrence of transitions in diverse professions (Evetts, 2009; Fenwick, 2013; Sawchuk \& Taylor, 2010). Field (2012) reflected that the boundaries and expectations of transitions through the life course are changing, both among individuals and in wider society. An OECD (Organisation for Economic Co-operation and Development) report (2008) noted that transitions are increasingly fragile and exclusionary and that the number of 'stepping stones' required to secure a labour market position is multiplying. Within this, individual learning and work transitions are becoming more challenging (Sawchuk \& Taylor, 2010). Individuals are being called on to manage transitions throughout their careers, beginning with the shift from initial post-school education to workplaces. All these observations underpin the critical need for education and work systems to pay attention to experiences of transitions.

The notion of transitions is also an important concept for understanding wider systemic articulation concerns, providing both structural and systemic insights. It can also provide empirical insights into how various qualifications may or may not articulate, and how changing contexts shape choices, needs and use related to available qualifications.

In reflecting on professionals' educational and occupational progression within environmental careers (Ramsarup, 2017), different dimensions of transitions emerge:

- From education to work (e.g. from a higher-education degree into a job);

- From work to education (e.g. from a job into further study);

- Within education and training systems (e.g. from a formal academic or professional degree course into an occupationally directed [short] course/s); and

- From occupational and work life into wider social processes (e.g. from engineering practice to societal processes providing normative assessments of the practice).

Against these dimensions of transitions, Sawchuk and Taylor (2010) asserted that learning and work transitions extend across the life course, and are increasingly complex, differentiated and differentiating across social groups. All these features raise questions about how transition-related processes can be more effectively managed by individuals, employers, education providers and national skills systems. This paper considers these factors, and how these need to be considered within changing societies and changing occupations, as well as what enables and constrains learning to work transitions in various contexts.

Understanding learning and work transitioning demands a focus on both the transition processes and outcomes, including stages of preparation, and actual transitions and outcomes in the labour market (Hannan, Raffe \& Smyth, 1996). This raises the significance of not viewing learning and work transitioning as a 'single point in time event'. Fenwick (2006) found that transition processes are also a process of identity development, which Ecclestone (2009:19) further described 
as a slow, subtle process of 'becoming somebody personally, educationally and occupationally'. This challenges more technical views of transitioning that are considered from the perspective of, say, access to education and training, or technical articulations and alignment between qualifications at the level of credits and/or credit transfer. Although these are vitally important as enablers within the broader processes of transitioning, the notion of transitioning processes provides a broader framework and lens through which such issues can be better understood.

Environmental occupations in South Africa typically do not have clearly defined institutionally or occupationally determined pathways (Ramsarup, 2017). The sector is characterised by professionals navigating their own non-linear pathway into a green job (Ramsarup, 2017). This has historical antecedents, most notably the recent emergence of such occupations on the national landscape and the lack of dedicated systems of education and training development for the environmental sector (DEA, 2010). Understanding learning to work transitioning into environmental occupations thus necessitates the use of theoretical ideas from boundaryless career discourse. This assists in more accurately describing and depicting the nature of the work and hence the transition experiences of environmental engineering professionals in these transitioning spaces, as described in this paper.

Boundaryless work is conceived of as the opposite of the organisationally determined career that is characteristically visualised to unfold in a single, pre-structured, vertical qualifications path or employment context. It is thus perceived as taking on many forms and has been described and depicted in various ways, such as:

- Movement across the boundaries of separate employers;

- Drawing validation from outside the present employer;

- Being sustained by networks and information external to the employer;

- Breaking traditional organisational career boundaries; and

- Perceiving a boundaryless future, regardless of structural constraints. (Arthur \& Rousseau, 1996:6; Roper, Ganesh \& Inkson, 2010)

Fenwick (2006) described boundaryless work as involving a sense of specialised expertise being developed and offered, with the career being marked by the development of specialised portable skills, knowledge and abilities. A second element is job mobility across multiple employers, erasing conventional boundaries defining job, workplace and employer. Other authors have added other characteristics of boundaryless work such as personal identification with meaningful work, on-the-job action learning, the development of multiple learning and peer-learning relationships, and individual responsibility for career management (Arthur \& Rousseau, 1996; Ensher, Murphy \& Sullivan, 2002).

\section{The Context of the Environmental Engineer in South Africa}

Internationally, environmental engineering is a recognised and established profession. In the United States of America (USA), it has a professional association in the form of the American Academy of Environmental Engineers and Scientists, founded as far back as 1967. The United Kingdom (UK), too, has the Society of Environmental Engineers. In Europe, the Confederation 
of European Environmental Engineering Societies has 12 member states and environmental engineering is offered as an undergraduate degree in several European countries.

In South Africa, a different scenario prevails, as a more integrative approach seems evident. The Engineering Profession Act (2000) states that the Engineering Council of South Africa (ECSA) will 'create an awareness amongst registered persons of the importance to protect the environment against unsound engineering practices', thus illustrating a policy framework that would appear to require all engineering disciplines to pay attention to environmental considerations.

There are no undergraduate qualifications in environmental engineering. The data informing the present paper (Ramsarup, 2017) shows that environmental engineering is a specialisation of certain engineering disciplines, especially civil and chemical engineering. Environmental engineering degrees are offered at several institutions in South Africa, but only at masters and doctoral level. These tend to specialise in water care, energy studies and environmental geography. Environmental engineering does not exist as a discipline independent of engineering. Thus, even after doing a masters degree, people 'cannot go around saying they are a professional in environmental engineering' (Trois, personal communication, 2013).

A demand for environmental engineers emerged in two national research processes. The Department of Environmental Affairs' national and provincial consultations during the development of the Environmental Sector Skills Plan for South Africa (DEA, 2010) and the scarce skills analysis of the Strategic Infrastructure Programmes (SIPs,${ }^{1}$ ) (DHET, 2013) both identified environmental engineering as a scarce skill. The Department of Higher Education and Training (DHET) thus declared environmental engineers as 'significantly scarce' $(20 \%-50 \%)$ and ' 300 environmental engineers had to be trained in the short term' (DHET, 2013, emphasis added). Five years ago, a study led by Du Toit and Roodt (2009:52) predicted that, 'with forthcoming environmental legislation and new emphasis being placed on environmental protection in South Africa, increased levels of graduation in environmental engineering will be necessary'. However, a coordinated sectoral response to this demand has not been articulated, neither within related engineering associations nor within the education and training system (National Qualifications Framework structures).

\section{Surfacing the Experiences of Transitions in Boundaryless Work among Environmental Engineering Professionals}

\section{Methodological process}

The present paper draws on an empirical study of career stories of environmental engineers. These career stories (Cohen \& Mallon, 2001) were developed following in-depth interviews

1 The Strategic Infrastructure Programmes are the implementation mechanism for the National Infrastructure Plan of the South African government. This National Infrastructure Plan is overseen by the Presidential Infrastructure Coordinating Commission (PICC). Eighteen SIPs have been identified, which have five core functions: to unlock opportunity, to transform the economic landscape, to create new jobs, to strengthen the delivery of basic services, and to support the integration of African economies. One of the focus areas is greening the economy (PICC, 2012). The DHET (2013) is developing an integrated skills development plan for the next 20 years across all the SIPS. 
and analysis of curricula vitae. The stories are drawn from a range of engineering consulting firms and an effort was made to interview individuals of diverse races and ages, for a diversity of stories and, therefore, wider views on the field.

The first layer of analysis focused on understanding the formal chronology of states and transitions in each of the environmental engineering professionals' lives, but also on the ways that they made sense of their transitions from learning to the work situation (i.e. development of the individual cases). This led to the construction of individually unique career stories that were then verified with the interviewees. Multiple layers of analysis of the career stories were then employed in order to deepen the analysis and unfold the underlying generative mechanisms in the individual cases. One layer of analysis focused on the key stages and transitions in the career stories. While people tell their stories very differently, this analytical process enabled the development of a framework for descriptive and analytical work related to the career stories. A further level of analysis using different analytical tools focused in more depth on the transition processes instead of on single events. This uncovered the relational and multifaceted nature of the environmental engineers' learning pathways. This multilayered analysis of the case stories was extended with a system analysis (e.g. analysis of the provisioning system of engineering qualifications, and of the operations and approaches of the professional associations, as briefly noted above in 'The Context...' above). For the present paper, the wider systems analysis is not included, as the focus here is on the transition experiences of the sampled environmental engineering professionals. More comprehensive insights on how the career stories and systems analysis 'come together' within a systems development perspective can be found in the $\mathrm{PhD}$ dissertation by Ramsarup (2017), which brings all these dimensions of the study of environmental sector learning pathways into focus in relation to one another.

Table 1 presents snapshots of the learning trajectories of the interviewees identified in their firms as environmental engineers (despite some not starting out as engineers). Learning pathways within the context of this study were conceptualised as educational and occupational progression (Ramsarup, 2017). Table 1 also reflects the diverse processes that encompass the transition into a specialisation. It should be noted that, while significant progress towards racial equity has been made in the broader engineering sector, this is not evident within the environmental engineering specialisation. We made many attempts to engage with more black environmental engineers, including trolling LinkedIn, but had limited success. Despite the fact that these individuals entered from different qualifications and specialisation paths (including chemical engineering, civil engineering and landscape architecture), their career stories reflected a strong preference for and intention to work in an environmental context, combined with engineering work options. The stories also demonstrated that transitioning into a specialised environmental work role presented many challenges, like organisational fit and sectoral and professional identity. The findings further highlighted the role that professional learning and professional networks play as people forge occupational identities within specialisations.

The interview data revealed many differing opinions on how environmental engineers should be viewed and trained in South Africa. This is discussed next. 
Table 1. Overview of interviewees' career stories: Key educational and work transitions

\begin{tabular}{|c|c|c|}
\hline Interviewee & Demographic & Story \\
\hline EE1 & White male & $\begin{array}{l}\text { Did a BTech (Civil Engineering), a BCom part-time, a Diploma } \\
\text { in International Project Management, and an MSc (Built } \\
\text { Environmental Sciences). Currently doing a PhD. Always had an } \\
\text { interest in human impact on the environment. Worked abroad in } \\
\text { Lesotho, Botswana and Nepal. Getting involved with the Green } \\
\text { Building Council gave him an opportunity to influence many } \\
\text { technical advisory teams in diverse sectors. The transition from } \\
\text { the engineering sector to the environmental sector took seven } \\
\text { years. Currently a sustainability consultant focusing on Green Star } \\
\text { energy-optimisation certification. }\end{array}$ \\
\hline EE2 & White male & $\begin{array}{l}\text { Obtained a degree in landscape architecture from the University } \\
\text { of Pretoria and was awarded a bursary by the Department of } \\
\text { Water Affairs (DWA). Used short courses and work experience to } \\
\text { develop his environmental career. Started off as a technician at the } \\
\text { DWA in a unit for 'special tasks'. Worked closely with engineers } \\
\text { at the DWA and created a new awareness about the environment. } \\
\text { Team synergy and mentorship at the DWA allowed him to build } \\
\text { on, and use, the environmental knowledge and experience of } \\
\text { the team. Later became an environmental consultant and took } \\
\text { on a different range of work, including spending six years on the } \\
\text { Lesotho Highlands Water Project. }\end{array}$ \\
\hline EE3 & White male & $\begin{array}{l}\text { Obtained an honours and a masters degree in Botany from Rand } \\
\text { Afrikaans University. Worked at the Department of Agriculture } \\
\text { for } 12.5 \text { years. Moved to the Department of Development Aid } \\
\text { as Head of Nature Conservation, which was later absorbed into } \\
\text { the Department of Environmental Affairs (DEA). Worked on } \\
\text { legislation and policy, including the National Environmental } \\
\text { Management: Biodiversity Act. Then left government and joined } \\
\text { an engineering firm as a private consultant. }\end{array}$ \\
\hline EE4 & Black male & $\begin{array}{l}\text { Always wanted to work in the environmental sector. Did a BSc } \\
\text { (Chemical Engineering) at the University of Cape Town (UCT) } \\
\text { because there were no undergraduate options for environmental } \\
\text { engineering. In his fourth year, attended a course in } \\
\text { environmental process engineering. Did his MSc (Environmental } \\
\text { Engineering) at the University of KwaZulu-Natal (UKZN), } \\
\text { which provided him with a broader environmental knowledge } \\
\text { base. Decided that environmental chemistry was the field for him. } \\
\text { First job was working with waste at a large engineering company. } \\
\text { Then moved to an environmental consulting company, which } \\
\text { was later taken over by a large engineering firm, which then sold } \\
\text { off the energy services unit. }\end{array}$ \\
\hline
\end{tabular}




\begin{tabular}{|c|c|c|}
\hline Interviewee & Demographic & Story \\
\hline EE5 & Indian female & $\begin{array}{l}\text { Had an interest in mathematics and science in school. Obtained a } \\
\text { BEng (Chem.) degree. In her fourth year, a talk on environmental } \\
\text { legislation excited her. She worked for the DWA, as well as on } \\
\text { a project dealing with acid mine drainage. This further ignited } \\
\text { her interest in the environment and in doing something good } \\
\text { for the planet. Next, she worked for a large oil company for two } \\
\text { years, where she witnessed some engineers showing complete } \\
\text { disregard for the environment in their planning and design. She } \\
\text { then moved to an engineering company which carried out } \\
\text { environmental-impact assessments and processed environmental } \\
\text { permits, mining applications, etc. After ten years, she left and now } \\
\text { works as an independent environmental engineering consultant } \\
\text { on engineering projects. }\end{array}$ \\
\hline EE6 & Indian female & $\begin{array}{l}\text { Obtained a BSc degree with honours in Medical Biochemistry } \\
\text { and Genetics, and then an MSc in Biotechnology and a PhD } \\
\text { in Civil and Environmental Engineering (focusing on organic } \\
\text { degradation and bacterial populations) at the University } \\
\text { of the Witwatersrand. She then worked at an engineering } \\
\text { company involved in waste management. Thereafter, she left } \\
\text { to pursue numerous researcher positions. Next, she worked as } \\
\text { a process engineer/environmental scientist at an engineering } \\
\text { company specialising in waste. She moved again and is } \\
\text { now an environmental/waste engineer at an international } \\
\text { engineering company. }\end{array}$ \\
\hline EE7 & White male & $\begin{array}{l}\text { Did a BSc (Civil Eng.) at the University of Pretoria. He worked } \\
\text { at a large national engineering company as a design engineer, } \\
\text { then left to join an environmental consultancy where he became } \\
\text { an associate. Next, he moved to an engineering company. } \\
\text { He currently works at a large engineering company as an } \\
\text { environmental engineer and auditor. }\end{array}$ \\
\hline EE8 & Black male & $\begin{array}{l}\text { Is not a South African and did his schooling and undergraduate } \\
\text { studies overseas. Originally from the Democratic Republic } \\
\text { of Congo, he studied in the UK and then worked there for } \\
\text { an engineering company focused on water issues. He became } \\
\text { involved in mining work and came to South Africa through } \\
\text { an international mining house. He currently works as an } \\
\text { environmental engineer in a large mining company. }\end{array}$ \\
\hline EE9 & White male & $\begin{array}{l}\text { Did his schooling in Europe and an undergraduate degree in } \\
\text { environmental engineering in Italy. He was employed by a } \\
\text { large international engineering consultancy, through which he } \\
\text { came to South Africa to support environmental projects. He } \\
\text { then did a masters degree in Environmental Engineering in } \\
\text { South Africa. He currently works in a large South African firm as } \\
\text { an environmental engineer. }\end{array}$ \\
\hline
\end{tabular}




\section{Insights into Occupational Mobility and Learning in the Transition to Specialised Work}

The data reflected two main mobility patterns. Firstly, in all the stories, there was considerable intra-organisational movement, largely in the form of lateral movement caused by engineering workplaces needing an 'environment' person for various project-based assignments. Secondly, there were frequent job moves between two organisational types, engineering consultancies and environmental consultancies. All the stories show this occupational and organisational change, which involved internal and external lateral movement in order to facilitate the development of specialist competencies. Table 2 shows the job moves of one interviewee. While this story is individually unique, other cases show a similar pattern.

Table 2. Extract from a career story of occupational progression

\begin{tabular}{|c|c|c|}
\hline & & Interviewee EE2 \\
\hline \multirow{5}{*}{$\begin{array}{l}\text { Work after } \\
\text { university } \\
\text { study }\end{array}$} & 1 & $\begin{array}{l}\text { Landscape architects and environmental planners } \\
\text { Vacation work }\end{array}$ \\
\hline & 2 & $\begin{array}{l}\text { Environmental consultancy } \\
\text { Environmental officer }\end{array}$ \\
\hline & 3 & $\begin{array}{l}\text { Engineering consultancy } \\
\text { Landscape architect } \\
\text { Associate }\end{array}$ \\
\hline & 4 & $\begin{array}{l}\text { Environmental consultancy } \\
\text { Associate } \\
\text { Senior associate } \\
\text { Director }\end{array}$ \\
\hline & 5 & $\begin{array}{l}\text { Engineering consultancy } \\
\text { Director and head of environmental division } \\
\text { Leader for Environmental Work in Africa in international engineering company }\end{array}$ \\
\hline \multicolumn{2}{|l|}{$\begin{array}{l}\text { Work during } \\
\text { study }\end{array}$} & $\begin{array}{l}\text { Landscape architects and environmental planners } \\
\text { Vacation work }\end{array}$ \\
\hline
\end{tabular}

The mobility pattern in Table 1 clearly depicts non-linear occupational progression. This is in contrast to the official engineering learning pathway maps, consisting of parallel ascending movements from undergraduate to candidacy to specialisation (Engineering Council of South Africa and engineering careers literature, as reviewed in Ramsarup, 2017). The environmental engineering pathways in this study show more (time-consuming) sideways movement in order to attain the levels of specialisation needed for high-level environmental engineering work.

Furlong, Cartmel and Biggart (2006) describe non-linear transitions as involving breaks, changes of direction, and unusual sequences of events. Non-linear transitions can include extended or repeated experiences of unemployment, frequent moves between jobs, and returns to education and training after periods in employment. However, the experiences of the South 
African environmental engineers detailed in this study do not match the Scottish experiences cited by Furlong et al. (2006), who conclude that people with high-level qualifications (especially a degree or equivalent) are more likely to follow linear, upward transitions. Rather, in the present study, it was found that South African engineers with high-level qualifications follow non-linear transitions in order to attain specialist competence in environmental engineering.

These mobility patterns challenge the idea of a linear developmental trajectory for environmental engineering professionals envisaged in the institutional pathway, as well as the normative pattern of an engineering pathway. There are complex lateral movements, catalysed by a growing need to address environmental issues and by an increase in environmental work noted by all interviewees, resulting in new needs in diverse and changing work contexts. These new needs and associated work experiences seem not to be adequately recognised within either the professional context or in the qualifications system. That more substantive attention needs to be given to the systemic dynamics of this occupation is borne out by the studies of the HSRC (2009), DEA (2010) and DHET (2013) which all found environmental engineering to be a scarce skill.

Within the career stories, the transition into the specialised field of environment-related work appeared to be 'unconscious' and somewhat ad hoc: one interviewee reflected that engineers 'stumble into this route in the workplace'. Only one of the interviewees had a deliberate intention to enter engineering and specialise as an environmental engineer. Nonetheless, all interviewees are currently regarded in their work contexts as practising environmental engineers. Interviewees were not able to pinpoint a turning point in their career trajectory into environmental work. Their stories illustrate that various exogenous factors prompted their deviation from their established career path, for example as a civil engineer. Labour market forces ultimately determine what work or project options are available, thus changing occupational configurations and creating new choices such as contract work. While supply and demand conditions were structural influences (Ibarra, 2004) on the transitioning process of these professionals, the personal adaption to this new work role can also be viewed as self-initiated, suggesting that agentive dynamics are also influential in the transitioning process. This work-role transition process is not guided by institutionalised transition processes but involves elements of separation and incorporation simultaneously. For example, a number of the engineers left engineering companies to work in environmental consultancies but subsequently returned to the engineering sector, and those who were in the engineering sector were seen as 'part outsiders', as their occupation was not a 'normal' version of engineering practices. Such occupational conditions make for a difficult transitionary process (Ibarra, 2004).

Another major issue was that the environmental engineers struggled to find their organisational fit, reporting that they did not have a clearly defined work role. As one interviewee reported, as 'the environmental guy' in the office he was always 'treading a fine line between being outspoken around environmental issues and maintaining the core business focus' of the engineering firm employing him. Several of the environmental engineers reported that they struggled to find a niche where they belonged. One interviewee, who also struggled with balancing business work and environment work, stated that it was 'difficult being an activist 
in a business'. Most of the engineers also had to wrestle with uncertainties and incomplete information, which are recognised features of a less-bounded organisation and of boundaryless work where people, contexts and processes are all always changing. Arthur and Rousseau (1996:21) noted that, in these instances of uncertainty: '[P]eople fill in the blanks [...] people making sense of uncertainty enact a structure in which to work. Micro-level processes shape macro-level organising.' All of the career stories reveal a dual learning process: a realisation of their own fluidity in continually escaping the fixed subject position allotted by the 'normal' engineering workplaces, and an engagement with 'external concerns' such as environmental issues, both of which reflect a growing awareness of their own subjectivities and their role in producing these subjectivities in the organisational context (Fenwick, 2006).

Livingstone and Scholtz (2010) remind us that individuals cope with changing environments by learning - and this is apparent from the career stories, all of which illustrate the significant role of learning throughout the life course. As work practices started to change and new work roles emerged, the need for regular and continuous learning became evident. The career stories all demonstrated transitions between different forms of learning, including formal and informal learning.

Formality and informality in learning is a relational continuum (Colley, Hodkinson \& Malcolm, 2003). However, for the sake of analytical discussion, it is necessary to make a distinction between these, as this enables elaboration on the full range of learning processes that these professionals engage in. Across the cases, work-based, experiential forms of learning were supplemented, largely by short course-based formal learning. The nine interviewees had, between them, completed 66 short courses. Of these courses, $44 \%$ were environment-related, $30 \%$ were engineering-related and $26 \%$ were general in nature (encompassing, for example, business writing, communication, computers, and power speaking). The dominance of environmental courses reflects their interest in and need to develop specialised environmental knowledge. The range of courses reflects different dimensions of an environmental specialisation, including: green building technologies; environmentally sustainable design; environmental law; integrated environmental management; energy efficiency technology; environmental-impact assessment; underground environmental control; and bioethics. The range of courses completed also reflects the consulting-work environments of the engineers and an articulated need for a diverse mix of environmental knowledge and skills. Some also reflected that they were reluctant to enter a postgraduate specialisation, as some of the masters courses were too specialised in one area (e.g. waste or water), which was not what they required for the more unfocused consulting industries in which they were working. Only two interviewees undertook a masters, in Environmental Engineering, and both indicated that it provided a 'language of interaction' but not the more in-depth knowledge they were seeking. The dominant, institutionally conceived pathway for formal learning and specialisation was not the preferred option of the practitioners interviewed.

The study illustrated that, in order to become environmental engineers, the engineers were of necessity and by choice actively engaging in upskilling and reskilling beyond organisational boundaries. They had taken active responsibility for their own learning and had subsequently crafted a path across and into a newly emergent field of practice. 


\section{Negotiating the Boundaries}

The discussion above helps to contextualise the transitioning experiences of engineers into an environmental engineering specialisation in South Africa, and indicates that, as described by Fenwick (2006:23) in her work on boundaryless careers, there is a certain form of 'freedom evident in the new practices and spaces of subjectivity that open in their nomadic movements across organisations, knowledges and working relationships'.

In this section, we highlight some of the dynamics of negotiating boundaries that have emerged. The career stories developed and analysed for this research have illustrated that the professionals concerned engage in crossing boundaries between organisations and occupations and, in the process, are creating new vocational identities.

While most research on occupational transitions has focused on initial career choice (Sullivan, 1999), this paper has illustrated that adults make occupational choices throughout their working lives and that the occupational focus in their career is strengthened as their area of specialisation is concretised. Tolbert (1996) emphasises that, as organisations become less important in defining career pathways, occupations will become more important. This suggests an increasing centrality of occupations in career arrangements (and potentially also in skills development system planning and provisioning). This would mean that people's occupationally based careers provide a means for signalling their ability and competence to employers and the labour market more broadly. This, in turn, requires a social understanding of the clearly defined set of skills and knowledge, and, in the case of the environmental engineering occupation, values. This social understanding sets a distinctive set of tasks against which these skills and knowledge can be applied in an occupation, and against which an occupational group member can be held responsible. This, Tolbert (1996) argues, lays the foundation for the occupational labour market - something that needs to be more carefully considered in the case of environmental engineering. Although it is now designated as an occupation within South Africa's formal occupational system, no clearly accepted occupational tasks and understandings have been defined (Ramsarup, 2017).

Fenwick (2006) recognised that boundaryless workers continually struggle with, and balance, the boundaries defining knowledge and scope of practice. These struggles are clearly depicted in the evidence of reversible transitions and the extended transitioning in the career stories outlined in Table 1. All the interviewees indicated that they had combined work and study, and they all experienced 'reversible transitions' where they moved in and out of education and paid work, engaged in work and full-time study at the same time, and learnt in different ways and different places.

The stories contain accounts of extended transitioning where some had taken up to eight years to gain their specialist subjective positions. For some, this involved multiple entry attempts, spells of unemployment, and periods of underemployment. The data indicates numerous lateral movements as environmental engineering professionals chose to gain experience in different work environments that enabled the development of specialist knowledge.

Blurred boundaries between education and work traverse these career stories, indicating that work and learning are inseparable for understanding the fullness of occupational transitions. 
Learning-to-work transitions that occur after occupational entry are complex and diverse, and also show that the nature of work cannot be separated from analyses of learning-to-work transitions, especially in a context where the occupational/work systems are undergoing transformation.

These stories illustrate that transitioning into work is not a single event, as all of the environmental engineers sampled were all working while studying and the work experience gained during their studies was critical for their occupational progression. While engaging in work, especially within new projects, the need for diverse forms of expert knowledge and specialised skill was highlighted, for example regarding new legislative, compliance and ethical demands.

Critical to skill specialisation and the development of specialised knowledge were the interdependent roles of work and experience, complemented by various forms of specialist training. All raised new demands, with the result that employees engaged in learning informally, but also in formal learning through short courses. Because boundaryless workers are not being developed to work for a particular firm, there is therefore a need to support the development of transferable skills in order to enable movement across organisational and occupational boundaries.

The career stories all confirm that networks are important in boundaryless work where people take responsibility for their own career paths. Interviewees all sought to belong to common groups and associations and to cultivate networks that could help them in providing information and in identifying career opportunities. Although the environmental engineers in this study all belonged to relevant associations of engineering professions, they all additionally sought to belong to 'other' environmental networks (e.g. the International Association for Impact Assessment, the Green Building Council and the Institute for Landscape Architecture in South Africa). Sullivan (1999) noted that professional networks provide boundaryless workers with a competitive edge in relation to career advancement, mobility and learning, and Arthur and Rousseau (1996) argued that networks serve as learning systems: gaining access to a network in effect means gaining access to another's knowledge and resources. Fenwick (2006) would also argue that networks may help the environmental engineers to define their subjectivity and subject position. The ambiguity of transition is mitigated within networks where individuals in transition have 'role models' and guiding figures that embody future possibilities, give advice and 'believe in the dream'.

Highlighting the need to pay attention to new work structures, Fenwick (2013) draws attention to inter-professional work that requires collaboration, with specialist professionals bringing diverse forms of expert knowledge to collaborative practice. This new work structure challenges boundaries of professions as 'expert domains'; boundaries may be recreated in new ways as practitioners are positioned to each represent their area of expertise in collaborative work. This demands new capacities among professionals who need to 'patch together diverse knowledges' and quickly negotiate work infrastructure and governance (Fenwick, 2013).

The stories of the environmental engineers all reflect that their transitional experiences were made significantly more complex by the fact that, within consulting environments, their work was largely project based. Reflecting on the shift to project-based work in the 
construction sector in Sweden, Ekstedt (2007) raised some pertinent points. Project-based work is characterised by tight deadlines and a focus on results and performance demands, which create stress. This was also reflected by one of the interviewees, who explained his experience of transitioning into project work as follows: 'Straight into consulting work was very difficult $[\ldots]$ it meant you already had to be a specialist within, without having worked in the processes, so you [were] thrown in the deep end and you eventually [discovered] how [the] processes [worked].' Ekstedt (2007) explained that individuals are learning throughout the project based on tasks that are their responsibility, resulting in companies often forfeiting training outside project work in favour of 'on-the-job training'. This results in promoting a 'transition from organisation-based knowledge to individual-based knowledge' (Ekstedt, 2007). A critical consequence of this transition is that individuals must assume more responsibility for their careers. Project-based work is focused on expertise and people have to market and profile their competence. Thus knowledge development and the way knowledge is developed and circulated in professional communities are important for understanding learning and work transitions.

\section{Some Implications for Organisations and Education and Training Systems}

Workplaces and education and training systems, in their role of supporting transitions, need to acknowledge that the way people enact their careers is changing. Boundaryless career practices require us to envisage career development and career guidance differently. Pathways need signposts (entry; work-based; non-institutional as well as professional), and people must learn how to navigate these, especially when destinations are not clear. All of the interviewees experienced challenges finding a path to a specialisation in environmental engineering, and, with the exception of one, all had little information on how they could specialise in this field as they entered the workplace.

Understanding access to specialisms is a critical consideration for career-guidance systems, where the emphasis is currently on entry into generic occupations (Ramsarup, 2017). Access into specialisms is not easy to represent, as detailed by a career-guidance specialist (FN3) interviewed for this study:

... more than one basic area of expertise they need to get under the belt, then a postgraduate and then you still needed to add something like short courses, or work experience, etc., etc. On top of that ... the researchers indicated that it was very difficult to plot and is not the advice you can give to a matriculant ... (FN 3)

However, we cannot ignore this need, especially when the demand for the skill has significant development implications. Messages about becoming an environmental engineer in South Africa are incomplete and mixed, as there does not appear to be a general systemic and clearly articulated understanding of what environmental engineering is in a South African context, of what work they do, and of what a candidate needs to study to become an environmental engineer. The study found inconsistencies in career information within the 
engineering sector and through the National Career Advice Portal. Universities are unable to give learners clear information on what to study, or how to get there. Within the Organising Framework for Occupations (OFO), environmental engineering has very recently been recognised as an occupation. However, observation data and field notes assembled for this study (Ramsarup, 2017) indicate that this recognition is not widely shared in the engineering sector. Some regard it as a specialisation of chemical engineering, some as a specialisation of civil engineering, and some (FN1, FN2) see it as an unnecessary job provision, indicating that civil-engineering teams can simply work with an environmental manager. This presents a challenge; if the labour market cannot clearly identify with the occupation, graduates are likely to struggle to get employment. This was reflected in one of the career stories that showed how a young graduate with a masters, in Environmental Engineering failed to secure a job for about eight months - despite it having being reported by national government as a 'scarce skill' occupation.

The following discussion by Breen (2005), reflecting on data from 27 OECD countries, is useful. He explains:

two key aspects determine how people fare once they leave education; the degree to which educational systems inculcate specific rather than general skill, and the extent to which there are direct links between education systems and employers... A greater emphasis on specific skills and a closer link between schools and employers lead to an easier transition from education to labour market, because they send a very clear signal to employers about the potential productivity of a given job seeker.

For smoother transitions, people need information, guidance and 'systemic articulation' (i.e. joined-up systems) that would enable the education system to signal, to the labour market, the suitability of a particular jobseeker for a particular job (Breen, 2005; Sawchuk \& Taylor, 2010). A further consideration would be the need for sector signalling into the education system. The present study could be seen as an example of how a sector may be signalling into the education system (e.g. via the DHET indicating a scarcity of 300 environmental engineers in a major developmental context, i.e. the SIPs skills planning processes). This case study also illustrates that the system has as yet not been able to respond to the demand for this occupation. It seems that the education system was unprepared and is now faced with trying to develop new skills with a pathway that is reliant on the agentic processes of individuals, without adequate systemic 'infrastructure' to respond to the substantive need.

The wider issue is that the education and training system in South Africa is reactively oriented to skills development for environmental work across a wide range of occupations and sectors, and thus requires substantive interventions to reorient to a more proactive orientation (DEA, 2010; HSRC, 2009; Lotz-Sisitka, Ramsarup, Gumede, Togo \& Rosenberg, 2013).

Policy perceptions of, and associated research into, educational transitions remain of critical importance, as explained thus by Te Riele (2004:247): 'The way policy conceptualises educational transition affects the structures and practices available to young people (through imposed reforms and funding), thus enabling some forms of transition and hindering others.' 


\section{Conclusion}

The transitioning experiences from these career stories illustrate how established engineering transition routes have become more protracted and unpredictable (Field, 2012). They are a reflection of how the emerging environmental discourse is being appropriated and assimilated into an established field of practice. The environmental engineers' career stories indicate the complexity of transitions and the need to pay attention to learning and work transitioning across organisational and occupational life. They thus also highlight implications for education and training system planning across subframework boundaries within the National Qualifications Framework. Transitioning provides a mechanism for researching coherence, collaboration, and possibilities for communication across a system and its subframeworks, each with their own differentiated form and function. The career stories thus demonstrate that assuming linearity ignores the complexity of transitions, as many students combine work and study, and engage in transitions between different forms of learning.

Raffe (2003) has emphasised that, to design effective education and training system policy (e.g. articulation policy), we need to understand the real pathway, as experienced in society, so that we can determine if the pathways on which policies are based correspond to it. If they do not, he argues, the policies could be flawed. He cautions that official pathways can become inaccurate when there has been rapid change. In the case of environmental engineers in South Africa, the experienced pathways (i.e. extended transitioning routes) may not be realistic in order to address the immediate demands of scarce skills and developmental priorities.

At a broader level, the present paper has demonstrated some of the problems with reactive approaches to skills planning that are linked to the emergence of new occupations and associated complexities. It raises the need for a review of the current supply platforms into environmental engineering, the need for more structured learning programmes for specialisms, and the need for extensive advocacy within the labour market so that these specialisms can be more broadly accepted.

\section{Notes on the Contributors}

Presha Ramsarup works in the Centre for Researching Education and Labour (REAL) at the University of the Witwatersrand, South Africa. Her recent $\mathrm{PhD}$ research focused on green skills learning pathways was aimed at investigating the nature of learning pathways for sustainable development and a green economy in South Africa.

Professor Heila Lotz-Sisitka holds a South African National Research Foundation Chair in Global Change and Social Learning Systems in the Environmental Learning Research Centre at Rhodes University, South Africa. Her work focuses on transformative learning and green skills learning pathways. It foregrounds collective agency for transformative change in society. 


\section{References}

Arthur, M.B. \& Rousseau, D.M. (1996). The boundaryless career as a new employment principle. In M.B. Arthur \& D.M. Rousseau (Eds), The boundaryless career. New York: Oxford University. (pp. 3-20)

Baruch,Y. (2006). Career development in organizations and beyond: Balancing traditional and contemporary viewpoints. Human Resource Management Review, 16(2), 125-138.

Breen, R. (2005). Explaining cross national variation in youth unemployment: Market and institutional factors. European Sociological Review, 21(2), 125-134.

Case,J. Issues facing engineering education in South Africa. http://www.academia.edu/195145/ Issues_facing_engineering_education_in_South_Africa, visited 24 April 2013.

Cohen, L. \& Mallon, M. (2001). My brilliant career? Using stories as a methodological tool in careers research. International Studies of Management and Organisation, 31(3), 48-68.

Colley, H., Hodkinson, P. \& Malcolm, J. (2003). Informality and formality in learning. A report for the Learning and Skills Research Centre. Lifelong Learning Institute, University of Leeds, London.

DEA (Department of Environmental Affairs). (2010). Environmental sector skills plan for South Africa. Pretoria.

DHET (Department of Higher Education and Training). (2013). Meeting the demand for SIPS scarce skills. Pretoria.

Du Toit, R. \& Roodt, J. (2009). Engineers in a developing country. The profession and education of engineering professionals in South Africa. Pretoria: HSRC.

Ecclestone, K. (2009). Lost and found in transitions. In J. Field, J. Gallacher \& R. Ingram (Eds), Researching transitions in lifelong learning. Hoboken, New Jersey: Routledge. (pp. 9-27)

Ekstedt, E. (2004). Paper presented at the EU-Japan Workshop on Corporate Social Responsibility and Changing Wage Systems - The role of trade unions, 26 \& 27 November 2004. Hitotsubashi University, Tokyo.

Ekstedt, E. (2007). A new division of labour:The 'projectification' of working and industrial life. Agire, 31-54.

Ensher, E.A., Murphy, S.E. \& Sullivan, S. (2002). The boundaryless career in the entertainment industry: Examining the employment experiences of executive women. In M.A. Peiperl, M.B. Arthur \& N Anand (Eds), Career creativity: Explorations in the remaking of work. Oxford: Oxford University. (pp. 229-254).

Evetts, J. (2009). New professionalism and new public management: Changes, continuities and consequences. Comparative Sociology, 8, 247-266.

Fenwick, T. (2006). Escaping/becoming subjects: Learning to work the boundaries in boundaryless work. In S. Billet, T. Fenwick \& M. Somerville (Eds), Work, subjectivity and learning: Understanding learning through working life. The Netherlands: Springer.

Fenwick, T. (2013). Understanding transitions in professional practice and learning. Towards new questions for research. Journal of Workplace Learning, 25(6), 352-367.

Field, J. (2012). Transitions and lifelong learning: Signposts, pathways, road closed? Lifelong Learning in Europe, 1, 5-11. 
Furlong, A., Cartmel, F. \& Biggart, A. (2006). Choice biographies and transitional linearity: Reconceptualising modern youth transitions. Revista de Sociologia, 79, 225-239.

Hannan, D.F., Raffe, D. \& Smyth, E. (1996). Cross-national research on school to work transitions: An analytical framework. Paper commissioned by the OECD Secretariat to provide background for the Transition Thematic Review. http://www.oecd.org/ dataoecd/39/59/1925587.pdf.

HSRC (Human Sciences Research Council). (2009). Guidelines towards a human capital development strategy in the biodiversity sector. Research report. Lewis Foundation \& the South African National Biodiversity Institute (SANBI). Pretoria: HSRC.

Ibarra, H. (2004). Career transitions and career change. INSTEAD Working Paper Series. France: INSTEAD.

Livingston, D.W. \& Scholtz, A. (2010). Work and learning in the computer era: Basic survey findings. In D.W. Livingston (Ed.), Lifelong learning in paid and unpaid work. Survey and research findings. New York: Routledge. (pp.15-57)

Lotz-Sisitka, H., Ramsarup, P., Gumede, M., Togo, M. \& Rosenberg, E. (2013). Green skills development in South Africa. System perspectives for the shaping of learning pathway possibilities for sustainable development, the green economy and climate resilient development. Unpublished Discussion Paper. Grahamstown: Rhodes University.

Ng, T.W.H., Sorensen, K.L., Eby, L.T. \& Feldman, D.C. (2007). Determinants of job mobility: A theoretical integration and extension. Journal of Occupational and Organizational Psychology, 80, 363-386.

OECD. (2000). From initial education to working life: Making transitions work. Paris: OECD.

OECD. (2008). Employment outlook 2008. Paris: OECD.

PICC (Presidential Infrastructure Coordinating Commission). (2012). A summary of the South African National Infrastructure Plan. Pretoria: Office of The Presidency.

Raffe, D. (2003). Pathways linking education and work: A review of concepts, research, and policy debates. Journal of Youth Studies, 6(1), 3-19.

Ramsarup. P. (2017). A critical realist dialectical understanding of learning pathways associated with two scarce skill environmental occupations within a transitioning systems frame. Unpublished PhD dissertation, Rhodes University, South Africa.

Roper, J., Ganesh, S \& Inkson, K. (2010). Neoliberalism and knowledge interests in career discourse. Work, Employment and Society, 24, 661-679.

Sawchuk, P. \& Taylor, A. (2010). Understanding challenging transitions in learning and work. In P. Sawchuk \& A. Taylor (Eds), Challenging transitions in learning and work. The Netherlands: Sense Publishers. (pp. 1-25)

Sullivan, S.E. (1999). The changing nature of careers: A review and research agenda. Journal of Management, 25(3), 457-484.

Sullivan, S.E. \& Baruch,Y. (2009). Advances in career theory and research: A critical review and agenda for future exploration. Journal of Management, 35(6), 1542-1571.

Te Riele, K. (2004). Youth transition in Australia: Challenging assumptions of linearity and choice. Journal of Youth Studies, 7(3), 243-257. 
Tolbert, P.S. (1996). Occupations, organisations, and the boundaryless career. In M.B. Arthur \& D.M. Rousseau (Eds), The boundaryless career. New York: Oxford University Press. (pp. 331-349) Wheelahan, L. (2009). Programs and pathway. A report prepared for the Pathways Project. School of Education and Professional Studies, Griffith University.

\section{Websites}

www.aaees.org, visited 24 April 2013.

www.ceees.org, visited 24 April 2013.

www.ecsa.co.za/about/SitePages/What\%20Is\%20ECSA.aspx, visited 24 April 2013.

www.engenius.org.za/Search.html?ordering=\&searchphrase=all\&searchword=environmental

+eng, visited 24 April 2013.

www.environmental.org.uk/content.php?p_id=1\&top, visited 24 April 2013. www.gostudy.mobi/careers/View.aspx?oid=550, visited 13 December 2013.

\section{Personal communication}

Trois, C. (7 August 2013), Dean of Engineering, University of KwaZulu-Natal, South Africa.

\section{Field notes}

FN1: SIPS Meeting with Consulting Engineers South Africa (CESA) (September 2013). FN2: SIPS Occupational Task Team meeting (30 September \& 1 October 2013).

FN3: Discussion with Eureta Rosenberg on PACE career resources (4 October 2013). 